\title{
COVID-19 Hastalarında Kardiyovasküler Değerlendirme
}

\author{
Ahmet AVCI ๑ $₫$, Naile ERIŞ GÜDÜL ๑ \\ Zonguldak Bülent Ecevit Üniversitesi, Tip Fakültesi, Kardiyoloji Anabilim Dalı, Zonguldak, Türkiye \\ Bu makaleye yapılacak atıf: Avcı A, Eriş Güdül N. COVID-19 Hastalarında Kardiyovasküler Değerlendirme. Türk Diyab Obez 2020;2: 147-154.
}

ÖZ

COVID-19'a neden olan SARS-CoV-2, ilk olarak Çin’in Hubei eyaletinde 8 Aralık 2019 tarihinde bildirildi. Hızla dünyaya yayılarak pandemi olarak kabul edildi. Tibbi, psikolojik ve sosyo-ekonomik birçok sonuçları olan SARS-CoV-2, sadece viral pnömoniye neden olmaz, kardiyovasküler sistemde de önemli etkilere sahiptir. Kardiyovasküler hastalık ile birlikte bulunduğunda COVID-19 daha yüksek ölüm oranı ile ilişkilidir. COVID-19, akut koroner sendrom, miyokardit, stres-kardiyomiyopati, aritmi, kardiyojenik şok ve kardiyak arrest gibi önemli kardiyovasküler komplikasyonların gelişimine de katkıda bulunur.

Anahtar Sözcükler: COVID-19, Kardiyovasküler hastalıklar, Kardiyovasküler değerlendirme

\section{Cardiovascular Assessment of Patients with COVID-19}

\begin{abstract}
SARS-CoV-2, which caused COVID-19, was first reported on December 8, 2019 in Hubei province, China. It quickly spread around the world and was officially accepted as a pandemic. It has multiple medical, psychological, and socio-economic consequences. Apart from viral pneumonia, SARS-CoV-2 also has adverse effects on the cardiovascular system. Together with pre-existing cardiovascular disease, COVID-19 is associated with a higher mortality rate. COVID-19 contributes to the development of serious cardiovascular complications such as acute coronary syndrome, myocarditis, stress-cardiomyopathy, arrhythmias, cardiogenic shock, and cardiac arrest.
\end{abstract}

Key Words: COVID-19, Cardiovascular disease, Cardiovascular assessment

\section{GİRIŞ}

Yeni koronavirüs (severe acute respiratory syndrome koranavirüs-2 [SARS-CoV-2]) ilk kez Aralık 2019'da nedeni bilinmeyen, tedaviye dirençli pnömoni olguları ile Çin'in Hubei eyaletindeki Wuhan şehrinde ortaya çıtı (1). SARS-CoV-2' nin neden olduğu COVID-19 hızla yayılarak XXI. yüzyılın ilk pandemisine neden oldu. Ülkemizde resmi olarak 11 Mart 2020 tarihinde de saptand, takiben olgu sayısı hızla artış gösterdi. Ölüm oranı en yüksek seyreden ve salgından en çok etkilenen grup, bilinen kardiyovasküler hastalıkları (KVH) olan ileri yaştaki kişilerdir (2). COVID-19 tanısını düşündüren bulgular başlıca solunum sistemi ile ilgili olsa da, kardiyak hasar bulguları hastaların önemli bir kesiminde görülür. Bu nedenle hastalığın KVH ile birlikteliği özellikle dikkate alınmaya başlanmıştır (3).

\section{EPIDEMIYOLOJI}

İlk kez Aralık 2019 ayında tespit edilmesine rağmen, Haziran 2020 ortalarına geldiğimizde dünya genelinde COVID-19 bulaşan kişi sayısı 7 milyonu geçti ve can kaybı 400 bine ulaştı. Salgından en fazla etkilenen ülke olan ABD'de vaka sayısı 2 milyon civarında, can kaybı ise 100 binin üzerindedir. Ülkemizde ise alınan sıkı önlemlere rağmen toplam vaka sayısı 170 binlere yaklaşıp ölen hasta sayısı 5 binlere ulaşmıştır. COVID-19 salgınının günlük durum raporları Dünya Sağlık Örgütü tarafından web sitelerinde yayınlanmaktadır (4). COVID-19 enfeksiyonu her iki 
cinsiyette de benzer enfeksiyon oranlarina sahip, ancak erkeklerde mortalite oranları daha yüksektir (5). KVH'nda COVID-19 prevalansının, dünya çapında ulusal gözetim ve veri toplama yöntemlerinin farklı olması nedeniyle tahmin edilmesi zordur. Hastalarda komorbid durumların bulunması, hastalığın şiddetinin daha da artmasına ve prognozun olumsuz etkilenmesine neden olmaktadır. Nisan 2020 tarihine kadar yayınlanan makalelerde COVID-19 pozitif olan ve ölen hastalardaki en yaygın eşlik eden durumlar özetlenmiştir (Tablo 1) (2).

\section{PATOFIZYOLOJI}

$\mathrm{KVH}$ patofizyolojisinde önemli bir yeri olan, akciğerlerden, kalpten ve damarlardan salınan anjiotensin konverting enzim (ACE2), renin anjiyotensin sisteminin (RAS) önemli bir üyesidir. SARS-CoV-2 hücrelere giriş için konağın ACE2 reseptörüne bağlanır (6). COVID-19 ile ilişkili $\mathrm{KVH}$, muhtemelen RAS/ACE2 sisteminin SARS-CoV-2 enfeksiyonu nedeniyle, hipertansiyon (HT) gibi komorbid durumlara bağlı olarak ortaya çıkan düzensizliğine bağlıdır. İnterlökin (IL)-6, IL-17 ve diğer sitokinlerin düzensiz salınımı ile $\mathrm{T}$ hücresi aktivasyonunun dengesizliğinden kaynaklanan sitokin salınım firtınası, COVID-19'da KVH gelişimine ayrıca katkıda bulunabilir. İmmünometabolizma değişiklikleri ile birlikte bağışıklık sisteminin aktivasyonu, plak kararlılığının bozulmasına ve akut koroner olayların gelişimine neden olabilir. Guzik ve ark.nın yayınladığ COVID-19'un kardiyovasküler tutulumunun varsayımsal mekanizması gösterilmiştir (Şekil 1) (7).

\section{COVID-19 KARDİYOVASKÜLER SİSTEM ÜZERINE ETKILERİ}

COVID-19 enfeksiyonunun kardiyovasküler sistem üzerindeki etkileri dört ana başlıkta özetlenebilir.

1. KVH varlığında, COVID-19 enfeksiyonunda hastalığın ciddiyeti ve ölüm riski artar.

2. Aritmi, miyokardit, miyokart hasarı ve venöz tromboemboli gibi çok sayıda KVH'ı içeren komplikasyonlarla doğrudan veya dolaylı ilişkilidir.

3. COVID-19 için kullanılan ilaçlar çeşitli KVH yan etkilerine sahiptir.

4. KVH bakım hizmeti veren sağlık çalışanları, ev sahibi veya taşıyıcı olarak virüs yayılımında rol oynabilmektedir. COVID-19 direkt KVH'a neden olabileceği gibi, KVH hastalık varlığında da COVID-19 enfeksiyonu gelişimi kolaylaşmaktadır (2).

COVID-19 nedeniyle yaşamını kaybeden hastaların büyük çoğunluğunda eşlik eden $\mathrm{KVH}$ mevcuttur. KVH olan ileri yaştaki kişiler virüsle karşılaştığı takdirde hastalığın ölümcül seyretme riski daha yüksektir. Bununla birlikte KVH'ı
Tablo 1: Covid-19 pozitif olup ölen hastalarda en yaygın eşlik eden hastalıklar.

\begin{tabular}{lcc}
\hline Hastalık & $\mathbf{n}$ & $\mathbf{\%}$ \\
\hline İskemik kalp hastalı̆̆ 1 & 145 & 30.1 \\
\hline Atriyal fibrilasyon & 106 & 22.0 \\
\hline İnme & 54 & 11,2 \\
\hline Hipertansiyon & 355 & 73.8 \\
\hline Diabetes mellitus & 163 & 33.9 \\
\hline Demans & 57 & 11.9 \\
\hline Kronik obstrüktif akciğer hastalığ 1 & 66 & 13.7 \\
\hline Aktif kanser (son 5 yılda) & 94 & 19.5 \\
\hline Kronik karaciğer hastalığ 1 & 18 & 3.7 \\
\hline Kronik böbrek yetmezliği & 97 & 20.2 \\
\hline Eşlik eden hastalık sayısı & & \\
\hline-0 & 6 & 1.2 \\
\hline-1 & 113 & 23.5 \\
\hline-2 & 128 & 26.6 \\
\hline-3 & 234 & 48.6 \\
\hline
\end{tabular}

bulunan genç yaştaki COVID-19 olgularında da ölüm oranları yüksektir (8).

\section{COVID-19 HASTALARINDA KARDIYYOVASKÜLER BELİRTILER ve TANI}

\section{Göğüs Ağrisı}

Aktif COVID-19 hastalarında gögüs ağrısı veya göğüste sıkışma hissi yaygındır. Genellikle iyi lokalize edilemez ve altta yatan pnömoni nedeniyle nefes darlığı ile birlikte bulunabilir. Gelişen derin hipoksemi, göğüs ağrısı, taşikardi ve miyokart iskemisini düşündüren elektrokardiyografik değiş̧ikliklere neden olabilir. Biyobelirteçlerin yükseldiği durumlarda, Tip 2 miyokart infarktüsünü (MI) düşündürebilir. Bununla birlikte, akut koroner sendromlu (AKS) hastalarda iskemi ile ilgili semptomlar daha tipiktir. COVID-19 enfeksiyonunda da nefes darlığ mevcut olabileceğinden ayırıcı tanı zorlaşır (9).

\section{Nefes Darlığ}

Nefes darlığ 1 , COVID-19 hastalarının tipik bulgularından biridir. Hastalık ilerledikçe nefes darlığı şiddeti de artar. Yoğun bakım ünitesine başvuran hastaların tamamına yakınında nefes darlığı mevcuttur (10).

\section{Öksürüik}

Öksürük, hastalık şiddetine bakılmaksızın COVID-19 olan hastaların yarısından fazlasında mevcuttur. Kuru öksürük daha sık gözlenirken balgamla birlikte de bulunabilir (10). 


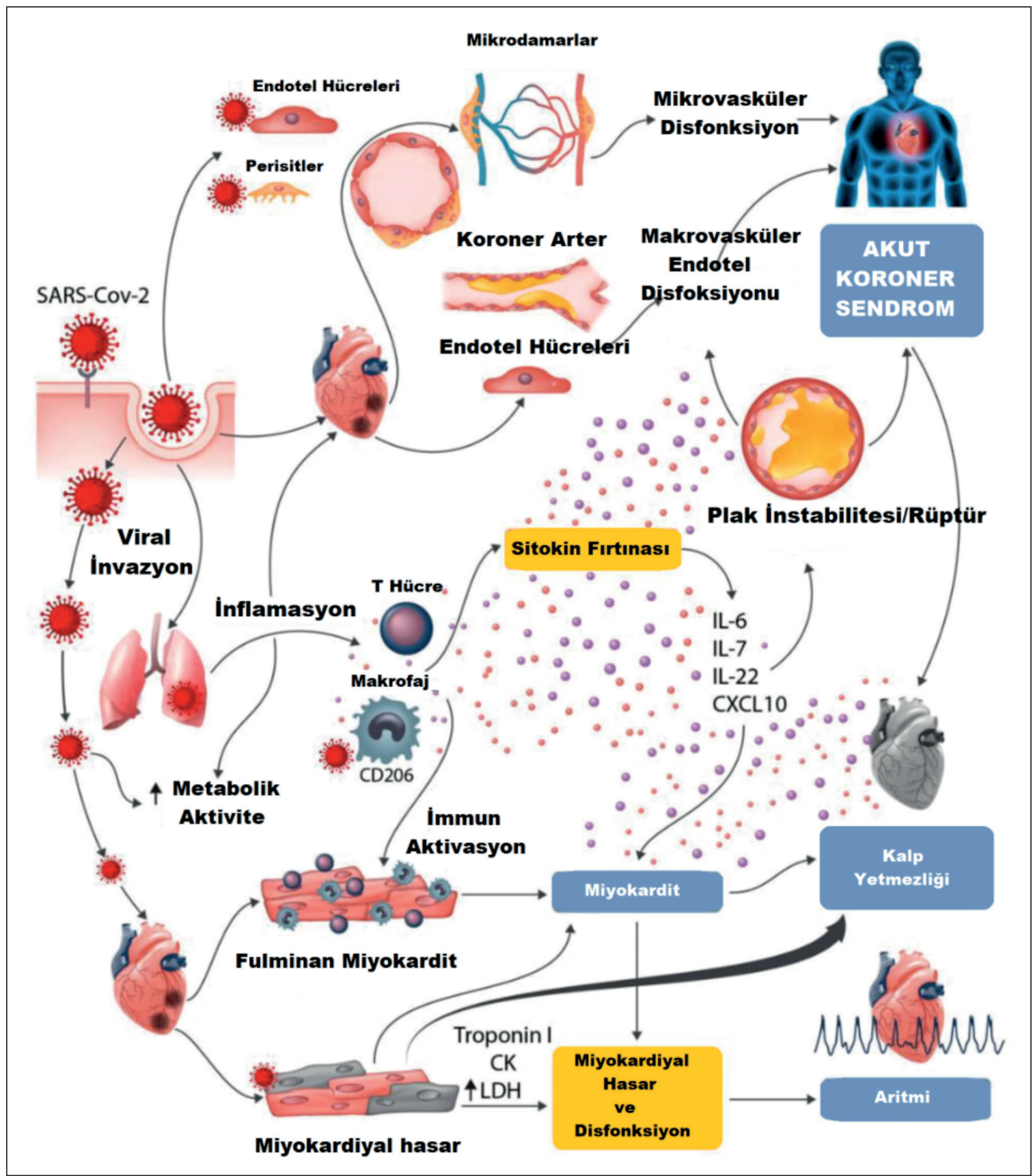

Sekil 1:

Covid-19'un kardiyovasküler tutulumunun varsayımsal mekanizması.

\section{Akut Solunum Sikıntı Sendromu (ARDS)}

ARDS diğer nedenlerle açılanamayan hipoksemi ile karakterize, göğsün görüntülenmesinde bilateral opasifikasyonların izlendiği durumdur. Hastanede yatan hastalarda ayak$\tan$ takip ve tedavi edilen hastalara göre daha sıktır. Hastalık başlangıcından ARDS' ye kadar geçen ortalama süre 8-12.5 gündür. İleri yaş ( $\geq 65$ yaş), komorbid durumların varlı̆̆g, nötrofili, lenfositopeni, organ disfonksiyonunun bulunuşu ve artmış laboratuvar belirteçleri izlendiğinde ARDS riski artar. COVID-19 hastalarında ARDS geliştiğinde ölüm oranları yükselir (11).

\section{Kardiyojenik Şok}

Kardiyojenik şok geliştiğinde (yaygın akut Mİ, sepsis vb) mümkün olduğunca kompleks etiyolojileri düşünmek gerekir. Miyokardit tetikleyici neden olarak düşünülmelidir. COVID-19 doğrulanmış veya şüphelenilmiş hastalarda erken, doğru ve hızlı tanı çok önemlidir. COVID-19 hastalarında kardiyojenik şokun kesin insidansı bilinmemektedir. Bununla birlikte, kritik hastalığ 1 olan COVID-19 hastalarında belirtilerin başlaması ile yoğun bakım ünitesine kabul arasındaki süre ortalama 9-10 gündür ve çoğu hastada solunumda kademeli olarak gittikçe ağırlaşan bir bozuklu- 
ğun olduğu görülmektedir. Kardiyojenik şok ve septik şok ayırıcı tanısında vazodilatasyon varlığ 1 , santral venöz oksijen satürasyon değerleri gibi parametreler kullanılabilir. Hemodinamik bozulma nedeni belirsiz olan hastalarda ve seçilmiş vakalarda, invaziv pulmoner arter kateteri yoluyla hemodinamik izleme yararlı bilgiler sağlayabilir. Ayrıca elektrokardiyogram, yatak başı ekokardiyografi ve acil koroner anjiyografi tanı için kullanılabilir $(12,13)$.

Hastane Dışı Kardiyak Arrest, Nabızsız Elektriksel Aktivite, Ani Kardiyak Ölüm, Taşiaritmiler, Bradiaritmiler

Bradiaritmiler ve taşiaritmilerin belirti ve bulguları normal klinik tablodan farklı değildir. SARS-CoV-2 virüsü enfeksiyonu ile ilişkili aritmi oluşumu hakkında sınırlı sayıda yayın mevcuttur. Hipoksemi ve sistemik hiperinflamasyon durumu, şimdiye kadar yayınlanmış bir veri olmamasına rağmen, yeni başlayan atriyal fibrilasyona yol açabilir. Bununla birlikte, ritim yönetimi, COVID-19 tedavisi, ilaç etkileşimleri ve antikoagülasyon dikkatle değerlendirilmelidir $(10,14)$.

\section{COVID-19, HİPERTANSIYYON ve TEDAVİSI}

İlk yayınlanan çalışmalarda HT başta olmak üzere eşlik eden KVH'ın varlığında COVID-19'a bağlı ölüm riskinde artış olmasıdır $(15,16)$. Çin'den yayınlanan ilk verilerde ARDS gelişen hastalarda HT tanısının daha sık olduğu belirtildi. Başka bir çalışmada da hastanede ölen COVID-19 hastalarında ölmeyenlere göre daha fazla oranda HT saptanmıştı (17). Araştırmacılar HT başta olmak üzere KVH ile COVID-19 arasında bağlantı olduğunu düşünüşler, bu da risk algoritmalarında HT tanısının ön sırada yer almasına neden olmuștur. Verilerin yorumlanmasında dikkatli olmak gerekir. Çünkü COVID-19'da en yüksek mortalite ve morbidite özellikle 60 yaş üstü kişilerde gözlenmektedir. COVID-19 ile ilgili yayınlanan çalışmalarda HT ile mortalite-morbidite arasındaki ilişki yaşa göre düzeltilmiş istatistik modellerinde incelenmemiştir. Dolayısıyla HT'un COVID-19 morbidite-mortalite açısından bir risk faktörü olarak görmek için veriler henüz yetersizdir. HT tanısı ile takip ve tedavi edilen kişilerle hipertansif olmayan kişilerdeki COVID-19 mortalite-morbidite hızlarını yaş ve ek risk faktörlerine göre karşılaştıracak çalışmalara ihtiyaç vardır (9).

SARS-CoV-2 konakçı hücresine girerken ACE2 reseptörünü kullanır. ACE2 ekspresyonunun yüksek olduğu tip II pnömositler ve enterositler, virüsün başlıca hedef hücreleridir. Viral RNA endositoz veya füzyon yoluyla hücre içine girerek hücreyi enfekte eder $(18,19)$. ARB ve ACE inhibitörlerinin viral bağlanma ve COVID-19 enfeksiyonu artıracağı endişesi antihipertansif tedavi protokollerinin tartışılmasına neden olmuştur. Mevcut çalışmalarda henüz SARS-
CoV2'nin solunum epiteli ve tip 2 pnömositlerde ACE2 yukarı ayarlanması ile ilgili bir veriye rastlanmamıștır. RAS blokerlerinin COVID-19'da etkinliklerini araştıran klinik/ preklinik çalışmalara her gün yenileri eklenmektedir (20, 21). Birincil ve ikincil koruma önlemlerine COVID-19' lu hastalar da diğer hastalar gibi ihtiyaç duyarlar. Şu andaki bilgilerimize göre, RAS blokerlerinin tedaviden çıkarılması uygun bulunmamaktadır (9).

\section{COVID-19, KORONER ARTER HASTALIĞI ve TEDAVİsi}

COVID-19' un AKS üzerindeki etkileri hakkında çok az şey bilinmektedir. Viral hastalıklarla ilişkili çeşitli yollar COVID-19 hastalarında koroner arterlerde plakların kararlı durumunun bozulmasina katkıda bulunabilir (22). Viral enfeksiyonlarda en yaygın Tip 2 Mİ gözlenir. Perisitlerin SARS-CoV-2 enfeksiyonu sirasında olası mikrovasküler inflamasyona bağlı ciddi mikrovasküler disfonksiyon gelişir. Sitokin fırtınası da iyi karakterize edilmiş mekanizmalarla endotel disfonksiyonunun gelişmesine katkıda bulunabilir ve obstrüktif olmayan koroner arterlerle miyokart enfarktüsüne neden olabilir. Bu nedenlerle COVID-19 hastalarında koroner revaskülarizasyona yönelik invaziv girişimler sınırlidir (23).

\section{ST YÜKSELMELİ MİYOKART ENFARKTÜSÜ OLGULARI}

ST-yükselmeli miyokart infarktüsü (STEMİ) ile müracaat eden hastalar için pandemi döneminde, bulaş riskinin en aza indirildiği anjiyografi laboratuvarı her an hazır bulundurulmalıdır. "Trombolitik tedavi" düşük riskli STEMI hastalarında iyi bir tercih olabilir. Kardiyojenik şok, yaygın anteriyor Mİ gibi hemodinaminin bozulduğu yüksek riskli hastalarda gecikmeden primer perkütan girişim uygulanmalıdır. Trombolitik tedavi uygulanan ancak ağrının devam ettiği, \%50 ST segment rezolüsyonu oluşmayan ya da kalp yetersizliği kliniği gelişen STEMİ hastalarında da "kurtarıcı" perkütan koroner girişim acilen uygulanmalıdır (2).

\section{ST YÜKSELMESİ OLMAYAN AKUT KORONER SENDROM OLGULARI}

Kardiyoloji uzmanları açısından değerlendirilmesi en zor durumlardan birisi de COVID-19'a bağlı miyokart hasarı ile AKS arasında ayırıcı tanı yapmaktadır. Hastalığın seyrinde solunum yetersizliği, hipoksi ve akut enflamasyon nedeniyle tip 1 veya tip 2 Mİ gözlenebilir (24). COVID-19'lu hastalarda "yüksek duyarlı" troponin değerlerinin hiçbir kardiyak yakınması olmayanlarda da yükseldiği gösterilmiştir (24). Troponin yüksekliği çoğunlukla miyokart hasarı lehinedir. Ancak, diğer birçok viral hastalıkta olduğu gibi COVID-19 enfeksiyonunda da koroner dışı birçok sebep ve mekanizma ile troponin yükselebileceği akılda tutulmalı- 
dır. AKS'nin tipik klinik ve EKG bulguları mevcut olsa bile COVID-19'lu hastalarında yüksek risk bulguları yoksa, acil anjiyografi ve girişim endikasyonu olmadığı düşünülmelidir (2). Maksimum medikal tedaviye rağmen iskemik semptomların devam etmesi durumunda ancak invaziv girişim düşünülmelidir. Salgın döneminde "acil olmayan" girişimlerin ertelenmesi ve genel olarak optimal medikal tedaviyi ön plana alan tedavi protokolleri tercih edilmelidir (2).

\section{COVID-19, MIYYKARDİYAL HASAR VE KALP YETMEZLİĞİ}

Kalp yetmezliği (KY) olan hastalar morbidite ve mortalite açısından yüksek riskli grubu oluşturur. Troponin düzeyleri artan hastalarda KY oranları daha fazladır (25). COVID-19 hastalarında mevcut KY'nin mi şiddetlendiği, yoksa yeni bir KY tablosunun mu geliştiği tam belli değildir. Akut akciğer ödemi gelişiminde tek başına kalp sorumlu olabileceği gibi, COVID-19 enfeksiyonu ile ilişkili veya karışık sebepler de bulunabilir. Ayırıcı tanıda, toraks bilgisayarlı tomografi faydalı bilgiler sağlar. COVID-19 pnömonisi ile takip edilen hastalardaki akciğer BT'de gözlenen KY arasındaki benzerlikler ve farklar özetlenmiştir (Tablo 2) (2). Plevral efüzyon sık olarak görülebilmektedir (26). ARDS tablosunda, ekokardiyografi ve beyin natriüretik peptit seviyeleri de ayırıcı tanıda kullanılabilir (27). COVID-19 enfeksiyonunun da

Tablo 2: Gögüs bilgisayarlı tomografisinde COVID-19 pnömonisi ve kalp yetersizliği arasında benzerlikler ve farklar.

\begin{tabular}{lcc}
\hline Özellik & Covid-19 & $\begin{array}{c}\text { Kalp } \\
\text { Yetmezliği }\end{array}$ \\
\hline Buzlu cam görüntüsü & +++ & +++ \\
\hline "Crazy paving" işareti & ++ & ++ \\
\hline Konsolidasyon & +++ & +++ \\
\hline Septal kalınlaşma & +++ & +++ \\
\hline Periferik dağılım & +++ & + \\
\hline Santral, basamaklı dağılım & + & +++ \\
\hline Dairesel lezyon & +++ & + \\
\hline Üç veya daha fazla lob & +++ & +++ \\
tutulumu & +++ & ++ \\
\hline Bilateral görünüm & ++ & + \\
\hline Peribronkovasküler kalınlaşma & - & +++ \\
\hline Pulmoner ven konjesyonu & - & +++ \\
\hline Kardiyomegali & + & ++ \\
\hline Plevral efüzyon & - & +++ \\
\hline $\begin{array}{l}\text { Kalp yetersizliği tedavisi ile } \\
\text { düzelme }\end{array}$ & & + \\
\hline
\end{tabular}

"Crazy paving": Anavut kaldırımı işareti. Buzlu cam görüntüsüyle birlikte interlobular ve intralobular septal kalınlaşmanın görülmesi. diğer viral enfeksiyonlar gibi, KY’ni kötüleştirme potansiyeli mevcuttur. Halen COVID-19 için bir aşı bulunamamıștır. Bununla birlikte KY olan tüm hastalara grip ve pnömoni aşıları önerilmelidir. Bu aşılar COVID-19 enfeksiyonunu önlemese de oluşabilecek ikincil enfeksiyonları önlemede önemlidir (2).

\section{COVID-19 ve MIYOKARDITT}

Miyokardit farklı klinik tablolarla ortaya çıkabilen, tanısının konulması ve gerçek insidansınının belirlenmesi zor olan bir hastalıktır. Ventrikül fonksiyonları normal veya hafifçe bozulmuş, hafif semptomları olan hastalarda miyokardit özel bir tedaviye gerek kalmadan genellikle kendiliğinden düzelir. Olguların \%30'unda ise dilate kardiyomiyopati gelişebilir (2). Dilate kardiyomiyopatiye ilerleyen olguların bir kısmında ventrikül iyileşmesi gerçekleşmezken bir kısmında tedavi ile geri dönüşümlü olabilir. Miyokarditte prognoz değişkendir. Altta yatan neden önemlidir. Viral enfeksiyonlar en sik miyokardit nedenidir. Viral miyokardit diyebilmek için, histolojik bulguların pozitif viral polimeraz zincir reaksiyonu (PCR) ile ilişkili olduğunun gösterilmesi gereklidir (28).

COVID-19 hastalarında miyokardit olguları bildirilmektedir. Henüz virüsün kalbi doğrudan enfekte ettiğine dair elimizde veri mevcut değildir. COVID-19 hastalarında sıklıkla troponin yükselmesi izlenmektedir, ancak sadece troponin yükselmesi ile miyokardit tanısı koymak doğru değildir. COVID-19 miyokarditinde direkt virüsle ilişkili hasardan çok oluşan immün yanıt ve sitokin firtınasının miyokarditin altta yatan temel mekanizması olduğu düşünülmektedir. (29). Miyokardit tanısını ve etiyolojisini belirleyen altın standart tanı yöntemi ise endomiyokardiyal biyopsidir. Kardiyak magnetik rezonans görüntüleme, biyopsi yapılamayan olgularda miyokardit tanısında kullanılabilir. Miyokardit düşünülen hastalarda Avrupa Kardiyoloji Kılavuzu'nun miyokardit tanı algoritması kullanılmalıdır (9). COVID-19 hastalığına bağlı gelişen miyokardit olguların tedavi ve takibinde kanıta dayalı bir tedavi şu an için yoktur.

\section{COVID-19 ve ARİTMİLER}

COVID-19 hastalarında aritmilerin meydana geldiği bilinmektedir (10). Tedavide kullanılan ilaçlar da proaritmik özellik taşımaktadır. Ventriküler aritmiler akut miyokardit olguları gibi ilk klinik bulgu olarak görülebilir. Hipokalemiye neden olan COVID-19'un RAS sistemi ile etkileşimi aritmiye neden olabilir. Yoğun bakım yatışını gerektiren hastalarda aritmi daha sık görülür. Malign ventriküler aritmiler, troponin değerleri yüksek olan hastalarda daha sık görülür (2). COVID-19 hastalarında hidroksiklorokin, azitromisin ve favipiravir gibi ilaçlar günlük kullanıma gir- 
miștir $(30,31)$. Yapısal ve genetik kalp hastalığı olanlarda, elektrolit bozukluğu bulunanlarda bu ilaçların "torsades de pointes" gibi ciddi aritmilere neden olma potansiyeli bulunmaktadır. Septik tablo, elektrolit dengesizliği, hipoksi, vazopressör/inotrop kullanımı ve miyokart enflamasyonunu gibi enfeksiyon sırasında gelişebilecek faktörler hastaların aritmik olay riskini daha da artırmaktadır. COVID-19 için antiviral, klorokin/hidroksiklorokin ve azitromisin başlanacak hastalar muhakkak tedavi öncesi aritmi riskini artırabilecek faktörler açısından değerlendirilmelidir (32). Tedavi başlangıcında ölçülen düzeltilmiş QT mesafesi (QTc), hastanede yatırılarak takip edilenlerde $500 \mathrm{msn}$, ayaktan tedavi edilenlerde 480 msn'den uzunsa ilaca başlama kararı risk-fayda analizi ile değerlendirildikten sonra başlanmalıdır. İzlemde QTc'de belirgin uzama (başlangıca göre 60 msn'den fazla veya 500 msn'nin üzeri olması) ve ventriküler ektopik vuru gözlenen hastalar monitörize edilmelidir. Kan elektrolit kontrolleri yapılarak uygun şekilde replasman yapılmalıdır. QTc'yi uzatan ilaçlar mümkünse kesilmeli, imkan varsa kalp hızı yükseltilmeli (isoproterenol infüzyonu, geçici pil veya varsa kalıcı pil uygulaması ile) ve dirençli aritmi tekrarında QT süresini kısaltıcı etkileri olan anti-aritmikler (Lidokain gibi) verilmelidir $(2,9)$.

\section{COVID-19 ve VENÖZ TROMBOEMBOLISSM}

İnflamatuvar durumların venöz tromboembolizm (VTE) riskini artırdığı bilinmektedir. Solunum yetmezliği, komorbid durumların varlığı, hareketsizlik COVID-19 hastalarında VTE riskini artırır (33). Yoğun bakım ünitelerinde takip edilen hastalarda D-dimer değerleri daha yüksek bulunmuştur. Yine COVID-19 nedeniyle ölen hastaların D-dimer değerleri de daha yüksek bulunmuştur. İleri yaş, düşük lenfosit düzeyleri diğer ilişkili risk faktörleridir. Özellikle komorbiditesi olan ileri yaştaki hastalarda VTE riski değerlendirilmeli ve önleyici tedaviler yerel yönergelere göre verilmelidir. Ayaktan izlenen komplikasyon gelişmemiş hastalar dışında hastaneye yatırılan tüm COVID-19 hastalarında ulusal ve uluslararası tedavi kılavuzları uyarınca tromboprofilaksi uygulanmalıdır (34).

Tromboproflakside ilaç etkileşimleri de göz önünde bulundurularak tercih düşük molekül ağırlıklı heparin olmalıdır. Mekanik protez kapağı bulunan ya da böbrek yetersizliği hastalarında standart fraksiyone olmayan heparin tercih edilebilir. Sık monitörizasyon gerektirdiğinden sağlı personelinin temasını, dolayısıyla bulaş riskini artırmaktadır (2). Ani gelişen dispne, oksijenasyonda kötüleşme ve/ veya hipotansiyon varlığında akut pulmoner emboli akla getirilmeli ve ekokardiyografi ile değerlendirilmelidir. En etkin tanı yöntemi kontrastlı bilgisayarlı akciğer tomografik anjiyografisidir. Hemodinamiyi bozan masif pulmoner emboli olgularında trombolitik tedavi açısından değerlen- dirilmelidir (35). Bilgisayarlı tomografinin kontrendike olduğu durumlarda ventilasyon/perfüzyon sintigrafisi ile değerlendirme yapılabilir. Hastalarda hastane yatışları süresince karantina nedeni ile mobilizasyon kısıtlı olduğu için antikoagülasyonun devamı önerilir (9).

\section{COVID-19 HASTALARINDA KALP İLAÇLARININ KULLANIMI}

KVH' da kullanılan ilaçların COVID-19 hastalarında kullanımına ilişkin veriler gün geçtikçe artmaktadır. "Türk Kardiyoloji Derneği COVID-19 uzlaşı raporunda ACE inhibitörü ve ARB grubundaki ilaçlarının kullanımı için bir engel bulunmadığı, bu nedenle hastaların tedavilerini aksatmaması gerektiği vurgulanır (2).

Akut koroner sendromda faydalı etkileri bilinen statinlerin kardiyovasküler komplikasyonları önleme ve tedavi konusunda olumlu etkileri mevcuttur. Bu nedenle statin kullanımına devam etmek mantıklı görünmektedir. Pleiotropik etkileri çok konuşulan statinlerin, bağışıklık sistemindeki aşırı sitokin salınımını kontrol ederek ve yoğun enflamatuvar yanıtı değiştirerek, immünmodülatör ve antienflamatuvar etki ile yararlı olabileceği de öne sürülmüsstür $(36,37)$. Bu nedenle, KVH' '̆ 1 bulunan COVID-19 hastalarında statin tedavisine güncel kılavuzlara uygun şekilde devam edilmesi ve hasta uyumunun özendirilmesi önemlidir.

Beta blokerlerin COVID-19 hastalarında kullanımı ve klinik olaylarla ilişkisini gösteren bir yayın yoktur. Sistemik inflamasyonunun plak rüptürü ve akut koroner olayları tetikleyebileceğini biliyoruz. COVID-19 pandemisi süresince plak stabilizasyonu sağlayabileceği düşünülen aspirin, statin ve beta blokerler gibi ajanların yararlı olabileceği düşünülmektedir (38). Beta blokerlerlerin hastanın klinik özelliklerine göre, güncel tanı ve tedavi kılavuzları çerçevesinde kullanılabileceği düşünülmektedir.

Nonsteroid antienflamatuvar ilaçlar konusunda tedbirli olmak gerekir. Bununla birlikte, aspirin kullanımının koroner olaylarda bugüne kadar sağladığı yararlar gözönüne alındığında kısıtlanmasına gerek olmadığı düşünülmektedir (39).

Hidroksiklorokin mevcut COVID-19 protokollerinin hemen hepsinde tekli veya kombinasyon tedavisi şeklinde önerilir. Akut veya kronik kullanımında kardiyak ritim bozukluklarina ve hatta torsades de pointes ritmine yol açabilir. QT uzamasına, ventriküler erken vurulara, ventrikül fibrilasyonuna ve ileri atriyoventriküler bloklara yol açabildiği de gösterilmiştir (40). Hidroksiklorokin ve azitromisin kombinasyonunun güvenliğini değerlendiren sınırlı güncel klinik veri vardır. Disritmik etkinliğin artabileceği her zaman akılda tutulmalıdır. COVID-19 için kombi- 
nasyon tedavisi planlanan hastalarm bazal 12 derivasyonlu elektrokardiyografilerinin ve ritim, PR, QRS ve düzeltilmiş QT intervallerinin tedavinin başında kayıt altına alınması hayli önemlidir. Tedavi süresince de günlük ritim, QTc, PR intervali ve QRS genişliği izlenmelidir. Magnezyum ve potasyum düzeylerinin yüksek normal düzeylerde tutulması ve ilaç dozlarının EKG intervallerindeki değişimlere göre ayarlanmalıdır (2).

\section{SONUÇ}

COVID-19, bugüne kadarki en önemli küresel acil sağlık durumu olarak sunuldu. COVID-19 ile ilgili araştırmalar tüm hızıyla devam etmektedir. KVH ile ilgili bilgilerin yakından takip edilmesi, mevcut yeni verilere göre tanı ve tedavi algoritmalarının yeniden gözden geçirilmesi büyük önem taşımaktadır.

\section{KAYNAKLAR}

1. Kang Y, Chen T, Mui D, et al. Cardiovascular manifestations and treatment considerations in covid-19. Heart. 2020;106(15): $1132-1141$

2. Aktoz M, Altay H, Aslanger E, et al. Türk Kardiyoloji Derneği uzlaşı raporu: COVID-19 pandemisi ve kardiyovasküler hastalıklar konusunda bilinmesi gerekenler. Türk Kardiyol Dern Ars. 2020;48(Suppl 1):1-87.

3. ACC Science and Quality Committee. Covid-19 clinical guidance for the CV Care Team. March 6, 2020.

4. Dünya Sağlık Örgütü yeni koronavirüs web sitesi adresi: (https://www.who.int/emergencies/diseases/novelcoronavirus-2019/situation-reports).

5. Clerkin KJ, Fried JA, Raikhelkar J, Sayer G, Griffin JM, Masoumi A, Jain SS, Burkhoff D, Kumaraiah D, Rabbani L, Schwartz A, Uriel N. COVID-19 and cardiovascular disease. Circulation. 2020;141(20):1648-1655.

6. Geng YJ, Wei ZY, Qian HY, et al. Pathophysiological characteristics and therapeutic approaches for pulmonary injury and cardiovascular complications of coronavirus disease 2019. Cardiovasc Pathol. 2020;47:107228.

7. Guzik TJ, Mohiddin SA, Dimarco A, COVID-19 and the cardiovascular system: Implications for risk assessment, diagnosis, and treatment options. Cardiovasc Res. 2020;116(10):1666-1687.

8. Verity R, Okell LC, Dorigatti I, et al. Estimates of the severity of coronavirus disease 2019: A model-based analysis. Lancet Infect Dis. 2020;20(6):669-677.

9. The European Society of Cardiology. ESC Guidance for the Diagnosis and Management of CV Disease during the COVID-19 Pandemic. Last updated on 21 April 2020.

10. Wang $\mathrm{D}, \mathrm{Hu} \mathrm{C}, \mathrm{Hu} \mathrm{C}$, et al. Clinical characteristics of 138 hospitalized patients with 2019 novel coronavirus-infected pneumonia in Wuhan, China. JAMA. 2020;323(11):10611069.
11. Ferguson N, Fan E, Camporota L, et al. The Berlin definition of ARDS: An expanded rationale, justification, and supplementary material. Intensive Care Medicine. 2012;38:1573-1582.

12. Baran DA, Grines CL, Bailey S, et al. SCAI clinical expert consensus statement on the classification of cardiogenic shock: This document was endorsed by the American College of Cardiology (ACC), the American Heart Association (AHA), the Society of Critical Care Medicine (SCCM), and the Society of Thoracic Surgeons (STS) in April 2019. Catheter Cardiovasc Interv. 2019;94(1):29-37.

13. Yang X, Yu Y, Xu J, et al. Clinical course and outcomes of critically ill patients with SARS-CoV-2 pneumonia in Wuhan, China: A single-centered, retrospective, observational study. Lancet Respir Med. 2020;(5):475-481.

14. Guo T, Fan Y, Chen M, et al. Cardiovascular implications of fatal outcomes of patients with coronavirus disease 2019 (COVID-19). JAMA Cardiol. 2020;5(7):1-8.

15. Huang C, Wang Y, Li X, et al. Clinical features of patients infected with 2019 novel coronavirus in Wuhan, China. Lancet. 2020;395:497-506.

16. Zhang JJ, Dong X, Cao YY, et al. Clinical characteristics of 140 patients infected with SARS-CoV-2 in Wuhan, China. Allergy. 2020;75(7):1730-1741.

17. Wu C, Chen X, Cai Y, et al. Risk factors associated with acute respiratory distress syndrome and death in patients with coronavirus disease 2019 pneumonia in Wuhan, China. JAMA Intern Med. 2020;180(7):1-11.

18. de Simone G, Mancusi C. Speculation is not evidence: Antihypertensive therapy and COVID-19. Eur Heart J Cardiovasc Pharmacother. 2020;6(3):133-134.

19. Patel AB, Verma A. COVID-19 and angiotensin-converting enzyme inhibitors and angiotensin receptor blockers: What is the evidence? JAMA. 2020. (Online ahead of print).

20. Sanchis-Gomar F, Lavie CJ, Perez-Quilis C, et al. Angiotensinconverting enzyme 2 and antihypertensives (angiotensin receptor blockers and angiotensin-converting enzyme inhibitors) in coronavirus disease 2019. Mayo Clin Proc. 2020;95(6):1222-1230.

21. McEvoy JW, et al. Coronavirus ACEi/ARB investigation. (Available at: https://clinicaltrials.gov/ ct2/show/NCT04330300. Accessed Apr 27, 2020.)

22. Musher DM, Abers MS, Corrales-Medina VF. Acute infection and myocardial infarction. N Engl J Med. 2019;380:171-176.

23. Levy BI, Heusch G, Camici PG. The many faces of myocardial ischaemia and angina. Cardiovasc Res. 2019;115:1460-1470.

24. Driggin E, Madhavan VM, Bikdeli B, et al. Cardiovascular considerations for patients, health care workers, and health systems during the coronavirus disease 2019 (COVID-19) pandemic. J Am Coll Cardiol. 2020;75(18):2352-2371.

25. Shi S, Qin M, Shen B, et al. Association of cardiac injury with mortality in hospitalized patients with COVID-19 in Wuhan, China. JAMA Cardiol. 2020;5(7):802-810. 
26. Shi $\mathrm{H}$, Han $\mathrm{X}$, Jiang $\mathrm{N}$, et al. Radiological findings from 81 patients with COVID-19 pneumonia in Wuhan, China: A descriptive study. Lancet Infect Dis. 2020;20(4):425-434.

27. Karmpaliotis D, Kirtane AJ, Ruisi CP, et al. Diagnostic and prognostic utility of brain natriuretic peptide in subjects admitted to the ICU with hypoxic respiratory failure due to noncardiogenic and cardiogenic pulmonary edema. Chest. 2007;131:964-971.

28. Caforio AL, Pankuweit S, Arbustini E, et al. Current state of knowledge on aetiology, diag- nosis, management, and therapy of myocarditis: A position statement of the European Society of Cardiology Working Group on Myocardial and Pericardial Diseases. Eur Heart J. 2013;34:2636-2648.

29. Channappanavar R, Perlman S. Pathogenic human koronavirüs infections: Causes and consequences of cytokine storm and immuno- pathology. Semin Immunopathol. 2017; 39:529-539.

30. Wang M, Cao R, Zhang L, et al. Remdesivir and chloroquine effectively inhibit the recently emerged novel coronavirus (2019-nCoV) in vitro. Cell Res. 2020;30:269-271.

31. Gautret P, Lagier JC, Parola P, et al. Hydroxychloroquine and azithromycin as a treatment of COVID-19: Results of an openlabel non-randomized clinical trial. Int J Antimicrob Agents. 2020;56(1):105949.

32. Tisdale JE, Jaynes HA, Kingery JR, et al. Development and validation of a risk score to predict QT interval prolongation in hospitalized patients. Circ Cardiovasc Qual Outcomes. 2013;6:479-487.
33. Khan IH, Zahra SA, Zaim S, et al. At the heart of COVID-19. J Card Surg. 2020;35(6):1287-1294.

34. Lee AYY, Connors JM, Kreuziger LB, et al. COVID-19 and coagulopathy: Frequently asked questions. (Available at: https:// www.hematology.org/covid-19/covid-19-and-coagulopathy. 2020).

35. Wang J, Hajizadeh N, Moore EE, et al. Tissue plasminogen activator (tPA) treatment for COVID-19 associated acute respiratory distress syndrome (ARDS): A case series. Thromb Haemost. 2020;18(7):1752-1755.

36. Vandermeer ML, Thomas AR, Kamimoto L, et al. Association between use of statins and mortality among patients hospitalized with laboratory-confirmed influenza virus infections: A multistate study. J Infect Dis. 2012;205:13-19.

37. Mehrbod P, Omar AR, Hair-Bejo M, et al. Mechanisms of action and efficacy of statins against influenza. Biomed Res Int. 2014;2014:872370.

38. Xiong TY, Redwood S, Prendergast B, et al. Coronaviruses and the cardiovascular system: Acute and long-term implications. Eur Heart J. 2020;41(19):1798-1800.

39. Wongrakpanich S, Wongrakpanich A, Melhado K, et al. A comprehensive review of non-steroidal anti-inflammatory drug use in the elderly. Aging Dis. 2018;9:143-150.

40. Khobragade SB, Gupta P, Gurav P, et al. Assessment of proarrhythmic activity of chloroquine in in vivo and ex vivo rabbit models. J Pharmacol Pharmacother. 2013;4:116-124. 